\title{
Effect of gonadotropin-releasing hormone analogue on final adult height among Jordanian children with precocious puberty
}

Hala H. Swaiss, MD, Nahla M. Khawaja, MD, FACE, Oraib H. Farahid, MSc, Anwar M. Batieha, MD, Dr.PH, Kamel M. Ajlouni, MD, FACE.

\begin{abstract}
الأهداف : لدراسة تأثير تماثلية هرمون الغدد التناسلية (GnRHa)

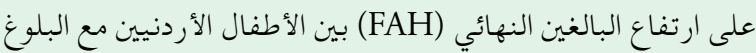

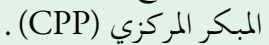

الطريقة : أجريت دراسة أترابية تاريخية بأثر رجعي. قمينا بتقييم

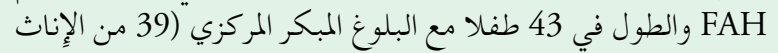

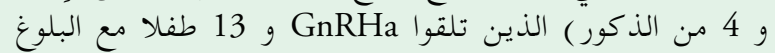

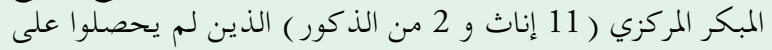
GnRHa

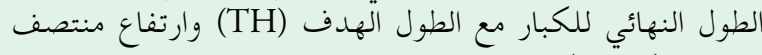
الوالدين (MPH) في كلتا المجموعتين.
\end{abstract}

النتائج : في الإناث المعالجين GnRHa

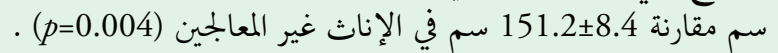

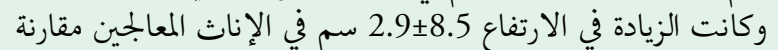

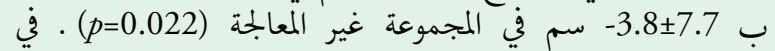

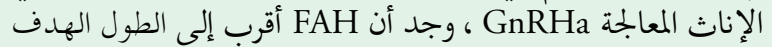
غير (المعان

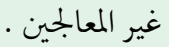

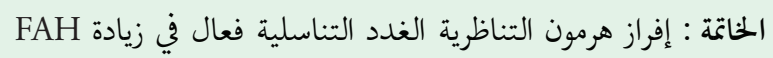

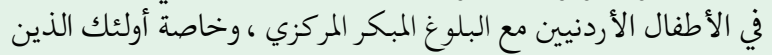

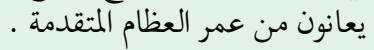

Objectives: To study the effect of gonadotropinreleasing hormone analogue $(\mathrm{GnRHa})$ on final adult height (FAH) among Jordanian children with central precocious puberty (CPP).

Methods: It is a retrospective historical cohort study. We assessed the FAH and height gain in 43 children with CPP (39 females and 4 males) who received GnRHa and 13 children with CPP (11 females and 2 males) who did not receive GnRHa and achieved FAH between 2004 and 2014. Final adult height was compared to target height (TH) and mid- parental height (MPH) in both groups.

Results: In GnRHa treated females, the FAH was $158.5 \pm 6.6 \mathrm{~cm}$ compared to $151.2 \pm 8.4 \mathrm{~cm}$ in the untreated females $(p=0.004)$. Height gain was $2.9 \pm 8.5 \mathrm{~cm}$ in the treated females compared to $-3.8 \pm 7.7 \mathrm{~cm}$ in the untreated group $(p=0.022)$. In GnRHa treated females, FAH was found to be closer to TH $(p=0.01)$ and MPH $(p=0.01)$ in comparison to untreated females.

Conclusion: Gonadotropin-releasing hormone analogue is effective in increasing FAH in Jordanian children with CPP, particularly those with advanced bone age.

Saudi Med J 2017; Vol. 38 (11): 1101-1107 doi: 10.15537/smj.2017.11.21187

From the National Center for Diabetics, Endocrinology and Genetics (Swaiss, Khawaja, Farahid, Ajlouni), University of Jordan, Amman, and from Department of Community Medicine (Batieha), Jordan University for Science and Technology, Irbid, Jordan.

Received 20th July 2017. Accepted 16th August 2017.

Address correspondence and reprint request to: Prof. Kamel Ajlouni, National Center for Diabetics, Endocrinology and Genetics, University of Jordan, Amman, Jordan. E-mail: ajlouni@ju.edu.jo

Drecocious puberty is defined as the development of 1 secondary sexual characteristics before the age of 8 years in females and 9 years in males. ${ }^{1,2}$ Precocious puberty can be either central which is gonadotropin-

Disclosure. Authors have no conflict of interests, and the work was not supported or funded by any drug company. 
dependent precocious puberty, or peripheral which is gonadotropin-independent precocious puberty. ${ }^{1,2}$ Premature activation of the hypothalamic-pituitarygonadal (HPG) axis causes central precocious puberty, which is more frequent in females and is usually idiopathic. ${ }^{1}$ Other causes of central precocious puberty include brain tumors, brain infections, brain ischemia, congenital brain defects, radiation or trauma to the brain or the spinal cord. ${ }^{1}$ Peripheral precocious puberty does not involve the HPG axis but it is caused by excessive secretion of estrogen and testosterone from the gonads and adrenal. ${ }^{1}$ Causes include congenital adrenal hyperplasia, adrenal tumors and gonadal tumors. ${ }^{1}$ As puberty speeds up growth, it ends up with a fusion of the epiphyseal plates of the long bones. ${ }^{3}$ Testicular androgen secretion in boys and estrogen secretion in girls induce pubertal spurt. ${ }^{4}$ In addition, estrogen in both sexes induce pubertal growth spurt and advancement of bone age, such an action is mediated by the estrogen receptors (ER- $\alpha$ and ER- $\beta$ ) in the human growth plates. ${ }^{4}$ Treatment of idiopathic central precocious puberty (CPP) is indicated; as such an abnormality leads to psychosocial problems in both the family and the affected child. ${ }^{5}$ Treatment is also indicated to improve Final Adult Height (FAH) and prevent the development of short stature due to the untimely fusion of long bone epiphyseal growth plates. ${ }^{6}$ Therefore, treatment should aim to halt physical maturation, prevent premature menarche and improve adult height. ${ }^{6-8}$ First synthesized in 1980, Gonadotropin Releasing Hormone analogues ( $\mathrm{GnRHa})$ has been extensively used in the treatment of CCP. ${ }^{9}$ As therapeutic agents, GnRHa desensitize and down-regulate GnRH-receptors, suppress gonadotropin secretion, and eventually reduce gonadal hormones to prepubertal levels. ${ }^{7}$ The monthly depot of $\mathrm{GnRH}$ analogue is therapeutically used to treat central precocious puberty as it causes a steady release of the drug with insignificant side effects. ${ }^{7-10}$ However, some investigators suggest that delaying puberty will not improve final height, because of the decreased rate of epiphyseal maturation that eventually attenuates the growth. ${ }^{6-11}$ Our center is a specialized referral center that deals with precocious puberty cases with a previously reported large series of cases with precocious puberty. ${ }^{12}$ Due to the high expenses of GnRHa in a poor country as Jordan and the controversy that was raised on final height achievement, we decided to investigate the effect of GnRHa on final adult height among Jordanian children with central precocious puberty.

Methods. A retrospective historical cohort study was conducted on all patients with precocious puberty who attended the National Center for Diabetes, Endocrinology, and Genetics (NCDEG), treated with
GnRH analogue (Triptorelin-SR, $3.75 \mathrm{mg}$ monthly injection) for at least one year and achieved their final adult height between 2004 and 2014 were enrolled in the study. A total of 43 patients met the inclusion criteria (39 girls and 4 boys), among these, 34 patients were previously reported. ${ }^{12}$ Data was collected from the medical records; pharmacy and laboratory databases. On the other hand, 13 patients with precocious puberty whose care givers refused treatment or could not afford it were considered as a control (untreated) group (11 girls and 2 boys). Precocious puberty was considered as the onset of breast enlargement before the age of 8 years old in girls (menarche before the age of 10 years) and testicular enlargement before the age of 9 years old in boys, the difference between bone age and chronological age $>1$ year and $\mathrm{LH}$ response to exogenous $\mathrm{GnRH}$ in the pubertal range. ${ }^{1,2,7}$ Most assays of stimulated $\mathrm{LH}$ consider the range of 3.3 to $5 \mathrm{mIU} / \mathrm{mL}$ as the upper limit of normal in prepubertal children, and values above that range suggest $\mathrm{CPP}^{7}$ Patients who received GnRHa for less than one year and those who were not compliant to treatment were excluded from the current study.

The National Center for Diabetics, Endocrinology and Genetics is a specialized referral center that deals with cases of precocious puberty. Usual care of patients involves regular follow up every 3 months with evaluation of the height, weight, Body Mass Index, growth rate and progression of pubertal signs. Yearly evaluation of the bone age is a routine practice in all cases of precocious puberty in our center. Adequate suppression during treatment was assessed by physical examination and regular follow up of the pubertal signs and by yearly evaluation of bone age. After discontinuation of GnRHa, patients were evaluated each subsequent year until the final height was achieved. Final adult height $(\mathrm{FAH})$ is measured at the time when growth velocity was less than one $\mathrm{cm}$ per year or at least 2 years after menarche in girls. ${ }^{13}$

Height is measured with a Harpenden stadiometer to the nearest $0.5 \mathrm{~cm}$ while standing up without shoes, the back kept in a vertical line with the stadiometer and the blades of the shoulders are parallel..$^{14}$ Pubertal staging is assessed according to Tanner staging system. ${ }^{15}$ Bone age is evaluated using the atlas of Greulich and Pyle (using the non-dominant hand and wrist). ${ }^{16}$ The predicted adult height is calculated by the method of Bayley and Pinneau, which has been found to be the most accurate method for patients with precocious puberty. ${ }^{17}$ We used the accelerated bone age tables in Bayley and Pinneau method. Mid parental height $(\mathrm{MPH})$ is defined as the average of the parental heights $\pm 6.5 \mathrm{~cm}(-6.5 \mathrm{~cm}$ for girls 
and $+6.5 \mathrm{~cm}$ for boys).$^{18}$ Target height $(\mathrm{TH})$ is calculated using the following formula: (sum of the height of the parents $+/-12) / 2+3 \mathrm{~cm}(+12$ for boys and -12 for girls). ${ }^{19}$ To assess the effectiveness of GnRHa therapy, the following outcome measures were used: Height gain (the difference between FAH and PAH at the start of therapy), ${ }^{20}$ difference between $\mathrm{FAH}$ and $\mathrm{TH}$, difference between FAH and $\mathrm{MPH}$, and proportions of patients who achieved $\mathrm{PAH}, \mathrm{TH}$ and $\mathrm{MPH}$.

Our study was approved by the local institutional ethics committee in our department which is accredited by the national ethics committee, and conducted in accordance with the declaration of Helsinki.

Statistical analysis. Treated and untreated groups were compared with respect to relevant variables at initial assessment and at reaching adult age. Differences in continuous variables were assessed for statistical significance using the independent $t$ test and differences in categorical variables were assessed for statistical significance using the chi-square test or the Fisher's exact test as appropriate. Percentages of treated and untreated subjects achieving predicted adult height, target height, and mid-parental height were obtained. Height gain was calculated and compared between the treated and untreated groups. To deal with potential confounding, multivariate linear regression was performed with final adult height as the dependent variable and treatment group together with other potential confounders as independent variables. The most parsimonious model which best fitted the data was reported. The Statistical Package for the Social Science version 19 (IBM Corp., Armonk, NY, USA) was used in data analysis.

When the analysis was performed, boys were removed from the group analysis because of the small number of boys and taking in consideration the difference between FAH expectations in boys and girls.

Results. At presentation, the mean age of the treated girls was $7.11 \pm 0.7$ years; the mean height was $131.3 \pm 9.2 \mathrm{~cm}$ and the mean bone age was $10.1 \pm 1.6$ years. A total of 11 girls with precocious puberty did not receive treatment and served as a control group. At presentation, their mean age was $7.3 \pm 0.6$ years, their mean height was $130.7 \pm 12.3 \mathrm{~cm}$ and their mean bone age was $10.0 \pm 1.9$ years.

Base line characteristics. The main axiological characteristics of the 39 treated girls and the 11 untreated girls are summarized in Table 1 . There were no significant statistical differences between treated and untreated groups regarding the age at presentation, height at presentation, bone age at presentation, MPH, $\mathrm{TH}$, and $\mathrm{PAH}$ at starting treatment.
Treatment was held at the age of $11.1 \pm 1.5$ years with a wide variation depending on multiple factors such as bone age, chronological age (CA) and height velocity.

Outcome measures. In the treated group, the achieved FAH was $158.5 \pm 6.6 \mathrm{~cm}$ compared to $151.2 \pm 8.4 \mathrm{~cm}$ in the untreated group ( $p=0.004)$, as shown in Table 1 .

The Height gain was $2.9 \pm 8.5 \mathrm{~cm}$ in the treated group compared to $-3.8 \pm 7.7 \mathrm{~cm}$ in the untreated group $(p=0.022)$ as shown in Table 2 . The mean difference between FAH and TH $(p=0.01)$ and the mean difference between FAH and MPH $(p=0.01)$ between the 2 groups was statistically significant.

Regarding males, the FAH was $167.2 \pm 7.6 \mathrm{~cm}$ in the treated boys compared to $149 \pm 12.7 \mathrm{~cm}$ in the untreated boys $(p=0.08)$. The height gain was $4.7 \pm 5.8 \mathrm{~cm}$ in the treated boys compared to $-6.4 \pm 8.4 \mathrm{~cm}$ in the untreated boys $(p=0.12)$. As shown in Table 3, the proportions of patients treated with GnRHa who achieved their predicted adult height was $51.3 \%$, target height was $20.5 \%$ and mid-parental height was $41 \%$.

The final adult height of the treatment group using multivariate linear regression. Multivariate linear regression analysis was performed to determine the independent effect of treatment on final adult height achievement after controlling potential confounders. In multivariate analysis treated patients', FAH was

Table 1 - Characteristics of the treated and untreated females patients with Gonadotropin-Releasing hormone analogue at the National Center for Diabetics, Endocrinology and Genetics.

\begin{tabular}{|c|c|c|c|}
\hline \multirow[t]{2}{*}{ Variables } & $\begin{array}{l}\text { Treated } \\
(\mathbf{n}=39)\end{array}$ & $\begin{array}{l}\text { Untreated } \\
(n=11)\end{array}$ & \multirow[t]{2}{*}{$P$-value } \\
\hline & \multicolumn{2}{|c|}{ Mean $\pm S D$} & \\
\hline Age at presentation (year) & $\begin{array}{c}7.11 \pm 0.7 \\
(5-8)\end{array}$ & $\begin{array}{c}7.3 \pm 0.6 \\
(6-8)\end{array}$ & 0.413 \\
\hline Bone age at presentation (year) & $\begin{array}{c}10.1 \pm 1.6 \\
(7-13)\end{array}$ & $\begin{array}{l}10.0 \pm 1.9 \\
(6.5-12)\end{array}$ & 0.891 \\
\hline Height at presentation $(\mathrm{cm})$ & $\begin{array}{l}131.3 \pm 9.2 \\
(111-146)\end{array}$ & $\begin{array}{c}130.7 \pm 12.3 \\
(110-146)\end{array}$ & 0.864 \\
\hline $\begin{array}{l}\text { Bone age - chronological age } \\
\text { (year) }\end{array}$ & $\begin{array}{l}2.8 \pm 1.3 \\
(0.5-5.5)\end{array}$ & $\begin{array}{l}2.7 \pm 1.4 \\
(0.00-4.5)\end{array}$ & 0.705 \\
\hline $\begin{array}{l}\text { Bone age/ chronological age at } \\
\text { initiation of treatment }\end{array}$ & $\begin{array}{c}1.40 \pm 0.2 \\
(1.07-1.83)\end{array}$ & $\begin{array}{c}1.35 \pm 0.2 \\
(1.00-1.6)\end{array}$ & 0.464 \\
\hline $\begin{array}{l}\text { Predicted adult height at } \\
\text { starting treatment }(\mathrm{cm})\end{array}$ & $\begin{array}{c}158.5 \pm 10.8 \\
(131-181)\end{array}$ & $\begin{array}{l}153.8 \pm 8.7 \\
(134-166)\end{array}$ & 0.190 \\
\hline Target height $(\mathrm{cm})$ & $\begin{array}{c}163.9 \pm 5.7 \\
(150.5-180)\end{array}$ & $\begin{array}{l}163.8 \pm 3.7 \\
(157-168)\end{array}$ & 0.949 \\
\hline Mid parental height $(\mathrm{cm})$ & $\begin{array}{l}160.4 \pm 5.6 \\
(147-176)\end{array}$ & $\begin{array}{c}160.4 \pm 3.6 \\
(153.5-164.5)\end{array}$ & 0.983 \\
\hline $\begin{array}{l}\text { Age at the end of treatment } \\
\text { (year) }\end{array}$ & $\begin{array}{l}11.1 \pm 1.5 \\
(6.5-14)\end{array}$ & - & - \\
\hline Duration of treatment (year) & $\begin{array}{c}3.0 \pm 1.4 \\
(1-6)\end{array}$ & - & - \\
\hline
\end{tabular}


Table 2 - Outcome measures in the treated and untreated female children.

\begin{tabular}{lccc}
\hline Variables & $\begin{array}{c}\text { Treated } \\
\text { Mean } \pm S D\end{array}$ & $\begin{array}{c}\text { Untreated } \\
\end{array}$ & $P$-value \\
\hline FAH $(\mathrm{cm})$ & $158.5 \pm 6.6$ & $151.2 \pm 8.4$ & 0.004 \\
& {$[136-176]$} & {$[140-165]$} & \\
Height gain (FAH - predicted height & $2.9 \pm 8.5$ & $-3.8 \pm 7.7$ & 0.022 \\
at starting treatment $)(\mathrm{cm})$ & & & \\
FAH - Target height $(\mathrm{cm})$ & $-5.3 \pm 7.5$ & $-12.5 \pm 9.1$ & 0.010 \\
FAH - MPH $(\mathrm{cm})$ & $-1.8 \pm 7.6$ & $-9.1 \pm 9.1$ & 0.010 \\
\hline \multicolumn{3}{c}{ FAH - final adult height, MPH - mid parental height } \\
\hline
\end{tabular}

Table 3 - Proportions of persons achieving the target, mid parental and predicted height.

\begin{tabular}{lccc}
\hline Variables & Treated & Untreated & $P$-value \\
& \multicolumn{2}{c}{$\mathbf{n}(\%)$} \\
\hline Target height ${ }^{*}(\mathrm{~cm})$ & $8(20.5)$ & $0(0)$ & 0.174 \\
MPH $(\mathrm{cm})$ & $16(41.0)$ & $2(18.2)$ & 0.287 \\
$\begin{array}{l}\text { Predicted height at starting } \\
\text { treatment }(\mathrm{cm})\end{array}$ & $20(51.3)$ & $5(45.5)$ & 0.733 \\
\hline \multicolumn{4}{c}{ *Fisher's exact test was used to obtain the p-value, } \\
MPH - mid parental height \\
\hline
\end{tabular}

Table 4 - Factors related to final adult height using multivariate linear regression.

\begin{tabular}{lcc}
\hline Variables & $\begin{array}{c}\text { Unstandardized } \\
\text { coefficient }\end{array}$ & $P$-value \\
\hline $\begin{array}{l}\text { Treated and untreated } \\
\begin{array}{l}\text { Predicted height at starting treatment } \\
(\mathrm{cm})\end{array}\end{array}$ & -7.26 & 0.001 \\
$\begin{array}{l}\text { Bone age/ chronological age at } \\
\text { initiation of treatment }\end{array}$ & 0.500 & 0.000 \\
\hline
\end{tabular}

$7.26 \mathrm{~cm}$ over untreated patients after adjustment for predicted adult height at starting therapy and bone age/ chronological age at presentation. The difference between the treated and untreated children in FAH was statistically significant $(p=0.001)$. As shown in Table 4, predicted adult height $(p=0.000)$, and bone age/ chronological age at initiation of treatment ( $p=0.029)$ were significantly related to final adult height achievement. For every $1 \mathrm{~cm}$ increase in PAH at starting therapy, the FAH increased by $0.5 \mathrm{~cm}$. In addition, for every 0.1 increase in the ratio between bone age and the chronological age at initiation of therapy, the FAH increased by $0.895 \mathrm{~cm}$.

Discussion. Based on our series of children with CPP who were treated for at least 1 year with the same protocol (a monthly single depot of GnRH analogue,
triptorelin-SR), our study showed that treatment with GnRH agonist can improve the statural outcome in children with CPP. Our data was also insightful in determining which factors influence the long-term axiological outcome in response to $\mathrm{GnRH}$ agonist in CPP children.

To assess the effect of GnRHa on statural growth, a comparison with predicted height and with a controlled group was done. The mean final adult height of our treated patients was $158.5 \pm 6.6 \mathrm{~cm}$, which is comparable to the FAH of the treated children in the studies of Arrigo et $\mathrm{al}^{21}(158.4 \mathrm{~cm})$, Klettert et $\mathrm{al}^{22}(157.9 \mathrm{~cm})$, Brauner et $\mathrm{al}^{23}(157.4 \mathrm{~cm})$, and Bouvattier et $\mathrm{al}^{24}(157.6$ $\mathrm{cm})$, as shown in Table 5. But it was lower than that reported by Carel et $\mathrm{al}^{25}$ in which the FAH of the treated girls was $161.1 \pm 5.9 \mathrm{~cm}$ and in the treated boys $172.8 \pm 6.4 \mathrm{~cm}$, as shown in Table 5 .

When compared to the untreated group, the FAH of our treated females was greater (FAH of the untreated girls in our study was $151.2 \pm 8.4 \mathrm{~cm} ; p=0.004)$, and also it was greater than the FAH in the untreated children in the studies of Sigurjonsdottir and Hayles et $\mathrm{al}^{26}$ $(152.7 \mathrm{~cm})$, and Paul et $\mathrm{a}^{27}(152.7 \mathrm{~cm})$. In multivariate analysis, treated patients gained about $7.26 \mathrm{~cm}$ over untreated patients after adjustment for PAH at starting therapy and bone age/ chronological age at initiation of treatment. The height gain in our treated children was $2.9 \pm 8.5 \mathrm{~cm}$ compared to $-3.8 \pm 7.7 \mathrm{~cm}$ in the untreated group $(p=0.022)$.

Similar to our findings, Pasquino et $\mathrm{al}^{28}$ followed $87 \mathrm{CPP}$ patients who were treated with GnRHa for $4.2 \pm 1.6$ years and 32 untreated patients with CPP; treated group achieved a statistically significant higher FAH $(159.8 \pm 5.3 \mathrm{~cm})$ and height gain $(5.1 \pm 4.5 \mathrm{~cm})$, compared to FAH $(154.4 \pm 5.9 \mathrm{~cm}, p<0.01)$ and height gain $(0.6 \pm 4.5 \mathrm{~cm}, p<0.001)$ in the untreated group.

Several studies showed significantly increased height gain in $\mathrm{GnRH}$ analogue treated patients. The outcomes were variable, ranging from $1 \mathrm{~cm}$ to $10 \mathrm{~cm} \cdot{ }^{27,29}$ This variation can be explained by the heterogeneity of the treated patients, the duration of the treatment, the used GnRH analogue protocol or due to different ways of prediction of adult height that is used; as some investigators used the average tables and others used the accelerated tables of Bayle-Pineau for prediction of adult height. ${ }^{22-25,27}$

Contrary to our findings, Bouvattier et $\mathrm{a}^{24}$ in his study, in which 20 Caucasian girls with advanced puberty were allocated to GnRHa treatment and compared to 10 untreated girls with advanced puberty, the FAH of the treated girls was $157.6 \pm 3.9 \mathrm{~cm}$, which is statistically comparable to the FAH of the untreated girls $(156.1 \pm 5.3 \mathrm{~cm}),(p=0.52)$. 
Table 5 - The effect of Gonadotropin-Releasing Hormone analogue on final height among children with precocious puberty in various studies.

\begin{tabular}{|c|c|c|c|c|c|c|c|}
\hline Study & $\begin{array}{l}\text { Number of } \\
\text { patients }\end{array}$ & $\begin{array}{c}\text { Onset of treatment } \\
\text { (year) }\end{array}$ & $\begin{array}{c}\text { Treatment duration } \\
\text { (year) }\end{array}$ & $\begin{array}{l}\text { PAH at start of treatment } \\
(\mathrm{cm})\end{array}$ & $\mathrm{TH}(\mathrm{cm})$ & FAH $(\mathrm{cm})$ & $\begin{array}{l}\text { Height gain } \\
(\mathrm{cm})\end{array}$ \\
\hline Carel $^{25}$ & 58 & $7.5 \pm 1.3$ & $3.7 \pm 1.5$ & $156.4 \pm 6.3$ & $160.1 \pm 4.4$ & $161.1 \pm 5.9$ & $4.8 \pm 5.8$ \\
\hline Arrigo $^{21}$ & 71 & $7.0 \pm 1.3$ & & $155.5 \pm 7.0$ & $161.5 \pm 6.9$ & $158.4 \pm 5.8$ & $2.9 \pm 6.0$ \\
\hline Pasquino $^{28}$ & $\begin{array}{c}87 \text { (treated) } \\
32 \text { (untreated) }\end{array}$ & $\begin{array}{l}8.4 \pm 1.5 \\
8.3 \pm 1.2\end{array}$ & $4.2 \pm 1.6$ & $\begin{array}{l}154.2 \pm 5.2 \\
155.1 \pm 4.3\end{array}$ & $\begin{array}{l}157.6 \pm 4.7 \\
158.5 \pm 4.8\end{array}$ & $\begin{array}{l}159.8 \pm 5.3 \\
154.4 \pm 5.9\end{array}$ & $\begin{array}{l}5.1 \pm 4.5 \\
0.6 \pm 4.5\end{array}$ \\
\hline Kletter $^{22}$ & 114 & 8.5 & 3.6 & & 161.4 & 157.5 & \\
\hline Brauner $^{23}$ & 10 & 8.8 & 3.1 & 153.4 & 159.1 & 157.4 & 4.0 \\
\hline Kauli $^{39}$ & 7 & 9.4 & 2.1 & 147.1 & & 150.3 & 3.2 \\
\hline Bouvattier $^{24}$ & 20 & 9.5 & 2 & 154.1 & 157.6 & 157.6 & 3.5 \\
\hline Current study & $\begin{array}{c}39 \text { (treated) } \\
11 \text { (untreated) }\end{array}$ & $\begin{array}{l}7.11 \pm 0.7 \\
7.3 \pm 0.6 \\
\end{array}$ & $3.0 \pm 1.4$ & $\begin{array}{c}158.5 \pm 10.8 \\
153.8 \pm 8.7\end{array}$ & $\begin{array}{l}163.9 \pm 5.7 \\
163.8 \pm 3.7\end{array}$ & $\begin{array}{l}158.5 \pm 6.6 \\
151.2 \pm 8.4\end{array}$ & $\begin{array}{r}2.9 \pm 8.5 \\
-3.8 \pm 7.7 \\
\end{array}$ \\
\hline
\end{tabular}

In our study, the mean difference between final adult height and predicted adult height at the start of the treatment was $2.9 \pm 8.5 \mathrm{~cm}$, which is higher than that reported by Carel et $\mathrm{al}^{25}(1 \mathrm{~cm})$ and Cassio et $\mathrm{al}^{30}(1 \mathrm{~cm})$ and less than that reported by Lazar et $\mathrm{al}^{31}(5 \mathrm{~cm})$ and Yanovski et $\mathrm{al}^{32}(4 \mathrm{~cm})$, but nearly similar to the height gain reported in the study of Bouvattier et $\mathrm{a}^{24}(3.4 \mathrm{~cm})$.

Our treated patients did not achieve their target height as shown in Table 2, as there was a significant difference between FAH and TH and only $20.5 \%$ of our treated patients achieved their TH. Our findings were similar to those of many other studies. ${ }^{21,25,33,34}$

We used the FAH rather than the height gain in our multivariate analysis in order to avoid errors associated with height prediction methods. The difference between the treated and untreated FAH was statistically significant $(p=0.001)$. As shown in Table 4, predicted adult height and bone age/ chronological age at starting therapy were independently and significantly related to final height achievement. Each of these factors was able to influence the statural outcome of our patients. The positive correlation between FAH and BA at the start of therapy was reported by Adan et al, ${ }^{35} \mathrm{Mul} \mathrm{D}$ et al ${ }^{36}$ Arrigo $\mathrm{T}$ et al, ${ }^{21}$ Bajpai et al.${ }^{37}$ and Liang $\mathrm{Y}$ et al. ${ }^{38}$ Whereas Carel et $\mathrm{a}^{25}$ found a negative association between BA/ statural age at the onset of treatment, his findings were attributed to the inability of GnRHa to restore adult height after an irreversible advancement of bone age.

Among our treated patients, no correlation between height gain and age at onset of puberty or at starting treatment could be established, this finding was previously reported by Carel et $\mathrm{al}^{25}$ Brauner et $\mathrm{al},{ }^{23}$ Pasquino et $\mathrm{al},{ }^{28}$ and kauli et al. ${ }^{39}$ Also, we found no correlation between height gain and treatment duration, same as Pasquino et al, ${ }^{28}$ Brauner et $a l,{ }^{23}$ and Jung MK et $\mathrm{al}^{43}$
The effect of using growth hormone-GnRHa combined treatment instead of GnRHa alone on final adult height in patients with precocious puberty is still controversial. Pasquino et al showed $6.3 \mathrm{~cm}$ difference in height gain in patients treated with GH plus GnRHa as compared to those treated with GnRHa alone. ${ }^{28}$ While Mo Kyung et al found no significant difference in height gain among the GnRHa alone treated patients and the growth hormone plus GnRHa treated patients. ${ }^{43}$ Even in children with idiopathic short stature and relatively early puberty, combined growth hormone-GnRHa therapy cannot be considered taking into consideration the modest effect on FAH, the extremely expensive parenteral therapy and the adverse effect on bone mineral density. ${ }^{44}$

The objectives of the current study were not previously evaluated in the Middle East or nearby countries. This study had some limitations; the objectives can be definitely achieved with a prospective randomized controlled study design. Furthermore, although the two groups (treated and untreated) had similar axiology at the start, it is possible that other confounding factors such as nutrition, psychosocial status, and genetic height expectations could influence the final adult height. Future prospective randomized controlled studies are needed in Jordan to assess the definite effect of GnRHa on $\mathrm{FAH}$ and to evaluate the presence of any adverse consequences of GnRHa, particularly on bone mineral density.

In conclusion, our study showed that GnRHa is an acceptable modality of treatment for improving FAH among Jordanian children with precocious puberty. Particularly those with higher PAH at starting treatment and higher bone age/ chronological age at initiation of therapy. 
Acknowledgment. All authors thank pharmacy, medical records, laboratory, and administrative staff for their help in accomplishing this study.

\section{References}

1. Fahmy JL, Kaminsky CK, Kaufman F, Nelson Jr MD, Parisi MT. The radiological approach to precocious puberty. $\mathrm{Br} J$ Radiol 2000; 73: 560-567.

2. Dixon JR, Ahmed SF. Precocious puberty. Pediatrics and Child Health 2007; 17: 343-348.

3. Cutler GB. The role of estrogen in bone growth and maturation during childhood and adolescence. J Steroid Biochem Mol Biol 1997; 61: 141-144.

4. Juul A. The effects of estrogens on linear bone growth. Human Reproduction Update 2001; 7: 303-313.

5. Sonis WA, Comite F, Blue J, Pescovitz OH, Rahn CW, Hench $\mathrm{KD}$, et al. Behavior problems and social competence in girls with true precocious puberty. J Pediatr 1985; 106: 156-160.

6. Sorgo W, Kiraly E, Homoki J, Heinze E, Teller WM, Bierich JR, et al. The effects of cyproterone acetate on statural growth in children with precocious puberty. Acta Endocrinol 1987; 115: 44-56.

7. Carel JC, Eugster EA, Rogol A, Ghizzoni L, Palmert MR. Consensus statement on the use of gonadotropin-releasing hormone analogs in children. Pediatrics 2009; 123: e752-762.

8. Heger S, Müller M, Ranke M, Schwarz HP, Waldhauser F, Partsch CJ, et al. Long-term GnRH agonist treatment for female central precocious puberty does not impair reproductive function. Mol Cell Endocrinol 2006; 254: 217-220.

9. Larsen PR, Kronenberg HM, Melmed S, Polansky KS. Puberty: ontogenety, neuroendocrinology, physiology and disorder. Williams textbook of endocrinology, physiology. 10th ed. Philadilphia (PA): Saunders; 2003. p. 1115-1239.

10. Lahlou N, Carel JC, Chaussain JL, Roger M. Pharmacokinetics and pharmacodynamics of GnRH agonists: clinical implications in pediatrics. J Pediatr Endocrinol Metab 2000; 13: 723-738.

11. Schoevaart CE, Drop SL, Otten BJ, Slijper FM, Degenhart HJ. Growth analysis up to final height and psychosocial adjustment of treated and untreated patients with precocious puberty. Horm Res 1990; 34: 197-203.

12. Taher BM, Ajlouni HK, Hamamy HA, Shegem NS, Madanat AY, Ajlouni KM. Precocious puberty at an endocrine center in Jordan. Eur J Clin Invest 2004; 34: 599-604.

13. Blethen SL, Baptista J, Kuntze J, Foley T, LaFranchi S, Johanson A. Genentech Growth Study Group. Adult height in growth hormone $(\mathrm{GH})$-deficient children treated with biosynthetic GH. J Clin Endocrinol Metab 1997; 82: 418-420.

14. Cameron N. The methods of auxological anthropometry. Human growth 1986; 31: 3-46.

15. Tanner JM. Growth and adolescence. 2nd ed. Oxford (UK): Blackwell Publishers; 1962.

16. Greulich WW, Pyle EI. Radiographic atlas of skeletal development of the hand and wrist. 2nd ed. Stanford (CA): Stanford University Press; 1966.

17. Bayley N, Pinneau SR. Tables for predicting adult height from skeletal age: revised for use with the Greulich-Pyle hand standards. J Pediatr 1952; 40: 423-441.

18. Sorva R, Tolppanen EM, Lankinen S, Perheentupa J. Growth evaluation: parent and child specific height standards. Arch Dis Child 1989; 64: 1483-1487.
19. Roede MJ. Growth diagrams 1980. Netherlands third national survey. Tijdsch Soc Gezondh 1985; 63: 1-34.

20. Guaraldi F, Beccuti G, Gori D, Ghizzoni L. Management of endocrine disease: Long-term outcomes of the treatment of central precocious puberty. European Journal of Endocrinology 2016; 174: R79-87.

21. Arrigo T, Cisternino M, Galluzzi F, Bertelloni S, Pasquino AM, Antoniazzi F, et al. Analysis of the factors affecting auxological response to $\mathrm{GnRH}$ agonist treatment and final height outcome in girls with idiopathic central precocious puberty. Eur J Endocrinol 1999; 141: 140-144.

22. Kletter GB, Kelch RP. Clinical review 60: effects of gonadotropin-releasing hormone analog therapy on adult stature in precocious puberty. J Clin Endocrinol Metab 1994; 79: 331-334.

23. Brauner R, Adan L, Malandry F, Zantleifer D. Adult height in girls with idiopathic true precocious puberty. J Clin Endocrinol Metab 1994; 79: 415-420.

24. Bouvattier C, Coste J, Rodrigue D, Teinturier C, Carel JC, Chaussain JL, et al. Lack of effect of GnRH agonists on final height in girls with advanced puberty: a randomized long-term pilot study. TJ Clin Endocrinol Metab 1999; 84: 3575-3578.

25. Carel JC, Roger M, Ispas S, Tondu F, Lahlou N, Blumberg J, et al. French study group of Decapeptyl in Precocious Puberty. Final height after long-term treatment with triptorelin slow release for central precocious puberty: the importance of statural growth after interruption of treatment. J Clin Endocrinol Metab 1999; 84: 1973-1978.

26. Sigurjonsdottir TJ, Hayles AB. Precocious puberty: a report of 96 cases. Am J Dis Child 1968; 115: 309-321.

27. Paul DA, Conte FA, Grumbach MM, Kaplan SL. The long-term effect of gonadotropin-releasing hormone agonist therapy on final and near-final height in 26 children with true precocious puberty treated at a median age of fewer than 5 years. J Clin Endocrinol Metab 1995; 80: 546-551.

28. Pasquino AM, Pucarelli I, Accardo F, Demiraj V, Segni M, Di Nardo R. Long-term observation of 87 girls with idiopathic central precocious puberty treated with gonadotropin-releasing hormone analogs: impact on adult height, body mass index, bone mineral content, and reproductive function. J Clin Endocrinol Metab 2008; 93: 190-195.

29. Stasiowska B, Vannelli S, Benso L. Final height in sexually precocious girls after therapy with an intranasal analog of gonadotrophin-releasing hormone (buserelin). Hormone Research in Paediatrics 1994; 42: 81-85.

30. Cassio A, Cacciari E, Balsamo A, Bal M, Tassinari D. Randomised trial of LHRH analog treatment on final height in girls with the onset of puberty aged 7.5-8.5 years. Archives of Disease in Childhood 1999; 81: 329-332.

31. Lazar L, Padoa A, Phillip M. Growth pattern and final height after cessation of gonadotropin-suppressive therapy in girls with central sexual precocity. J Clin Endocrinol Metab 2007; 92: 3483-3489.

32. Yanovski JA, Rose SR, Municchi G, Pescovitz OH, Hill SC, Cassorla FG, et al. Treatment with a luteinizing hormonereleasing hormone agonist in adolescents with short stature. $N$ Engl J Med 2003; 348: 908-917.

33. Galluzzi F, Salti R, Bindi G, Pasquini E, Cauza C. Adult height comparison between boys and girls with precocious puberty after long-term gonadotrophin-releasing hormone analog therapy. Acta Paediatrica 1998; 87: 521-527. 
34. Bertelloni S, Baroncelli GI, Sorrentino MC, Perri G, Saggese G. Effect of central precocious puberty and gonadotropin-releasing hormone analog treatment on peak bone mass and final height in females. Eur J Pediatr 1998; 157: 363-367.

35. Adan L, Chemaitilly W, Trivin C, Brauner R. Factors predicting adult height in girls with idiopathic central precocious puberty: implications for treatment. Clin Endocrinol 2002; 56: 297-302.

36. Mul D, Bertelloni S, Carel JC, Saggese G, Chaussain JL, Oostdijk W. Effect of gonadotropin-releasing hormone agonist treatment in boys with central precocious puberty: final height results. Horm Res 2002; 58: 1-7.

37. Bajpai A, Sharma J, Kabra M, Gupta AK, Menon PS. Long-acting $\mathrm{GnRH}$ analog triptorelin therapy in central isosexual precocious puberty. Indian Pediatrics 2002; 39: 633-639.

38. Liang Y, Wei H, Li J, Hou L, Zhang J, Wu W, et al. Effect of GnRHa 3.75 mg subcutaneously every 6 weeks on adult height in girls with idiopathic central precocious puberty. $J$ Pediatr Endocrinol Metab 2015; 28: 839-846.

39. Kauli R, Galatzer A, Kornreich L, Lazar L, Pertzelan A, Laron Z. The final height of girls with central precocious puberty, untreated versus treated with cyproterone acetate or GnRH analog. Horm Res 1997; 47: 54-61.
40. Guaraldi F, Beccuti G, Gori D, Ghizzoni L. Management of endocrine disease: Long-term outcomes of the treatment of central precocious puberty. Eur J Endocrinol 2016; 174: R79-87.

41. Kumar M, Mukhopadhyay S, Dutta D. Challenges and controversies in diagnosis and management of gonadotropin dependent precocious puberty: an Indian perspective. Indian J Endocrinol Metab 2015; 19: 228.

42. Kim EY. Long-term effects of gonadotropin-releasing hormone analogs in girls with central precocious puberty. Korean $J$ Pediatr 2015; 58:1-7.

43. Jung MK, Song KC, Kwon AR, Chae HW, Kim DH, Kim HS. Adult height in girls with central precocious puberty treated with gonadotropin-releasing hormone agonist with or without growth hormone. Ann Pediatr Endocrinol Metab 2014; 19: 214-219.

44. van Gool SA, Kamp GA, Visser-van Balen H, Mul D, Waelkens JJ, Jansen M, et al. Final height outcome after three years of growth hormone and gonadotropin-releasing hormone agonist treatment in short adolescents with relatively early puberty. $J$ Clin Endocrinol Metab 2007; 92: 1402-1408. 